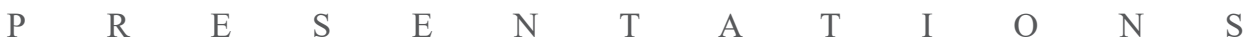

\title{
Kris Salata
}

Florida State University, USA

IN SERVICE OF THE LIVING WORD

Some Thoughts on Reducie na stulecie: studia i rozpoznania

\author{
W służbie żywosłowia
}

Kilka uwag o tomie Reducie na stulecie: studia i rozpoznania 


\begin{abstract}
Conceived as a symbolic gift to honor Teatr Reduta on the centennial of its inception, the extensive volume entitled Reducie na stulecie: studia i rozpoznania [Reduta on Its Centennial: Studies and Interpretations] does more than commemorate and celebrate: it advances the studies of one of the most original and deeply influential undertakings in Polish theatre, which, despite securing its emblematic place in history, deserves a closer analysis from the contemporary perspective and further dissemination among scholars and practitioners. Reading the book from across the Atlantic Ocean, the author will add, that this need for continued rethinking of theatre in dialogue with Osterwa and Limanowski in the current Polish cultural and political context seems to be as important as it is challenging. On the one hand, the religious and spiritual underpinnings of Reduta may be particularly susceptive to "committed" interpretations, to use Adorno's term. On the other hand, memories bring the threat of nostalgia and sentimentalism that help to mythologize rather than analyze unique phenomena. Has Reducie na stulecie managed to stay free from these historiographic traps? What value do these history lessons bring to us today?
\end{abstract}

Keywords: Juliusz Osterwa, Mieczysław Limanowski, Reduta, theatre laboratory, experimental theatre

\begin{abstract}
Abstrakt: Obszerny tom Reducie na stulecie: studia i rozpoznania, pomyślany jako symboliczny prezent dla uhonorowania setnej rocznicę powstania Teatru Reduta, nie tylko upamiętnia i celebruje: jest kontynuacją studiów nad jednym z najbardziej oryginalnych i wpływowych przedsięwzięć w polskim teatrze. Reduta zajmuje emblematyczne miejsce w historii, ale zasługuje na bliższą analizę z perspektywy współczesnej, a także na upowszechnienie wśród badaczy i praktyków teatru. Czytając tę książkę po drugiej stronie Atlantyku, dodam, że potrzeba ciągłego rewidowania naszego spojrzenia na teatr w dialogu z Osterwą i Limanowskim w aktualnym polskim kontekście kulturowym i politycznym wydaje się tyleż ważna, ile wymagająca. Z jednej strony religijne i duchowe podstawy Reduty mogą być szczególnie podatne na „zaangażowane” interpretacje, by użyć określenia Adorno. Z drugiej strony związane z Redutą wspomnienia prowokują nostalgię i sentymentalizm, które raczej mitologizują niż pomagają analizować to zjawisko. Czy Reducie na stulecie udało się uwolnić od tych historiograficznych pułapek? Jaką wartość przynoszą nam dziś te lekcje historii? (Przet. E. Olechnowicz)
\end{abstract}

Słowa kluczowe: Juliusz Osterwa, Mieczysław Limanowski, Reduta, laboratorium teatralne, teatr eksperymentalny 
Reducie na stulecie: studia i rozpoznania, pod red. Dariusza Kosińskiego i Wandy Świątkowskiej, Instytut Teatralny im. Zbigniewa Raszewskiego, Warszawa 2019

\begin{abstract}
Conceived as a symbolic gift to honor Teatr Reduta on the centennial of its inception and dedicated to the memory of the recently passed theatre historian, Zbigniew Osiński, this extensive volume does more than commemorate and celebrate: it advances the studies of one of the most original and deeply influential undertakings in Polish theatre, which, despite securing its emblematic place in history, deserves a closer analysis from the contemporary perspective and further dissemination among scholars and practitioners. Reading the book from across the Atlantic Ocean, I will add, that this need for continued rethinking of theatre in dialogue with Osterwa and Limanowski in the current Polish cultural and political context seems to be as important as it is challenging. On the one hand, the religious and spiritual underpinnings of Reduta may be particularly susceptive to "committed" interpretations, to use Adorno's term. On the other hand, memories bring the threat of nostalgia and sentimentalism that help to mythologize rather than analyze unique phenomena. Has Reducie na stulecie managed to stay free from these historiographic traps? What value do these history lessons bring to us today? (And, by "today," I mean, during the time of the global ontological reset). Isn't it fair to start looking at things we care about from the perspective of an Artaudian plague literally checking the integrity of our aspirations?

The collection distributes its focus along the established themes in the historiography of Reduta, while, of course, attempting to elaborate and expand on them. Agnieszka Wanicka writes on Reduta's radical departure from the tradition and conventions of "old" theatre, noting that at least in the dedication to craft through hard daily work one can find an element of continuity between the Reduta actors and the true stars of the Star System, such as Helena Modrzejewska. There is never a clean and complete break away from tradition, she may be telling us in the sub-
\end{abstract}


text behind her rhetorical maneuver, and T. S. Eliot, in his consideration of tradition and the individual genius would likely agree. Katarzyna Flader-Rzeszowska writes on Edmund Wierciński, emphasizing the two most important words for the actor: work and love. Work here means "work on oneself" (intellectual and spiritual) as much as on technique and craft. Ksenia Lebiedzińska focuses on the mastery of Wanda Osterwina's acting, insisting that Osterwina embodied the Reduta ideal for the actor, i.e. the priestess of ceremony. Commenting on Reduta's legacy, Jan Jiř́k concentrates on Osterwa's influence on the interwar Czech theatre. In the realm of notable productions, Krystyna Duniec writes on Żeromski's Uciekta mi przepióreczka, and Diana Poskuta-Włodek, on Dobrodzicki's staging of Ulica Dziwna - an avant-garde formalist work, also set against Reduta's conventions and principles, but in agreement with Reduta's concept of autonomous theatre. Dorota Jarząbek-Wasyl chose the rather rarely discussed subject of Radio Reduta. Barbara Osterloff describes the rocky relationship between Zelwerowicz and Osterwa, while Natalia Jakubowa writes on Irena Solska. Agnieszka Marszałek focuses on Reduta's persistently bad press, Anna Kuligowska-Korzeniewska, on the company's success in Łódź, Jarosław Cymerman, on Osterwa's peculiar impact in Lublin, Wojciech Dudzik, on Reduta's mission as an actual Polish National Theatre, and Dorota Buchwald, on Reduta's famous tours. This, in the nutshell, describes the content of several chapters of the book (14 of 21 total), but not its core, which, in my mind, has to do with the questions I posed above.

Indeed, from the pages of colorful stories and sparkling anecdotes one can begin to perceive deeper philosophical foundations of the Osterwa and Limanowski project - not merely the means and methods, but the essential motivation behind them. I said "perceive" rather than "formulate" or "express," because autonomous theatre, which Reduta ultimately developed, banks on the nonconceptual and nondiscursive content of human experience.

In his own chapter, Dariusz Kosiński rightly states that while scholars have generally accepted Grotowski's presentation of Reduta as Poland's first theatre laboratory, the discussion of the productions rarely highlights the research thread of the work. Thus, Kosiński wants to reconstruct performances judging their value in the context of the long-term practical research rather than their contemporary commercial or artistic success. A closer look at the staging of Tetmajer's Judasz - a production in many ways unremarkable outside of the title role played by Stefan Jaracz - provides clues for Kosiński about Osterwa and Limanowski's early attempts at the genre of mystery plays. At stake here is Reduta's radical ontology: theatre is not an entertainment or a didactical exercise with a dose of aesthetic pleasure. Rather, it is a realm of experience and communication through experience; it is an intersubjective transmission of themes impossible to disseminate through rational thought carried by language. That's why the form (product) is not 
as much a staged production but an ongoing laboratory work (process). Reduta was not a studio preparing actors for actual employment later or elsewhere, but rather a form capable of achieving its goals directly through artistic research and pedagogy. In other words, the actors were being conditioned and prepared to perform the very daily tasks that provided for them a chance of fulfillment as artists and human beings. Plays, roles, staging practices merely provided the means for the extraordinary, and often cathartic, encounter between the performers themselves in the service of both the material and the spectators-witnesses. That's why it is not an interpretation of a play that Reduta would stage, but the play's very self - its own being - its thingness. Reduta's productions were not an expression of ideology or faith, but a complex, nondiscursive testimonial able to provide experiential understanding and revelation. Kosiński goes further and, considering the political circumstances of 1922, when the play was staged, he proposes that Judas' struggle between his commitment to the holy mission and his untamed desires provides a meaningful commentary for the citizens of the restored Polish state settling into the new reality and perhaps taking it for granted. One could find in the temptations of petty life a sense of betrayal of the higher cause. By pointing to this individual and tribal moral dilemma, Kosiński comments on Poland's situation a century ago as well as in the present moment.

In a rare cross-disciplinary analysis between Catholic theology and theatre, priest Andrzej Draguła writes on Osterwa's concept of the "living word." For Osterwa, the preacher and the actor both deal with the "living word." They both pray in a liturgy attended by others who also pray by their participation: "Theatre is a mysterious site where a mysterious mass takes place." Both the priest and the actor speak the word, thus speak on its behalf (in its spirit). They also both speak on behalf of other characters from the stories, biblical or secular, even if only by the means of empathy. This "feeling for," which may become "feeling as," represents. It does so not mimetically but as a deed itself - the performer (preacherpriest-actor) serves in the ceremony offered to those who prepared it as well as those who attend it (parishioners, spectators, witnesses). Osterwa spells out the means of the performer: word, voice, gesture. Draguła makes sure we understand that Osterwa draws his similarity between the actor and the preacher, and not the actor and the priest, for the latter possesses a special license. However, both the actor and the preacher speak words that are not their own, yet which become their own in the process. By reaching out to his field's literature, Draguła tries to unpack the meaning of the "living word," which, as it seems, calls for the emotional investment of the performer (love of God), as well as some formal, aesthetic craft (speech and gesture). As such, the "living word" belongs to theological rather than rhetorical order. So far, we have not departed from Osterwa's findings, and have not gained anything particularly new from the religious discourse on the 
preacher's efficacy. But when Draguła quotes Apostle Paul, "the letter kills, but the spirit revives," we find ourselves in the territory of the "speech versus writing" contest, introduced in Western culture by Plato. This departure takes us away from Osterwa's point about the "living word," as not all speech is capable of delivering it, but only the one that reveals the heart.

Draguła repeats Kosiński's thesis that a "living word" must have transcendental powers and adds that these powers come from the spirit through/as breath. Kosiński's playful line quoted by Draguła ends the article with the long-awaited punch: it is not about staging a liturgy, but rather, it is about celebrating a play. I still ask, what could the "licensed speaker" tell us about his experience with the spirited word? Is it by the means of that license that the speech act becomes felicitous? To what degree does the religious perspective provide a new interpretation, beyond J. L. Austin' theory of performative utterances and Turner/Schechner's theory of ritual?

The ritual theme shows up, even if marginally, in Maria Kalinowska's chapter on Limanowski's attempt to summarize and describe his connection to Osterwa (after the actor's death). There, in a short piece of writing, Limanowski's passion for the values established and grounded during his and Osterwa's formative period in Moscow and throughout Reduta's work shows itself with the force as if he were a young theatre adept and not a tired, 72-year old man a year before his death. This passion manifests some fundamental hope for theatre to become a form of life through art and a transformative secular ritual event - a dream which also fueled other visionaries such as Artaud, Sulerzhitsky, Meyerhold, Copeau, and later, Grotowski.

There is enough material in the volume to think about the "essence of the Polish culture" which Reduta sought in the language of Romantic dramatic poetry, whether that of the Bards of the historical period or of its indulgent echo in the Young Poland movement. It is a more rewarding route because Osterwa's and Limanowski's search for essence is always simultaneously the search for the inner (nondiscursive) experience, if we borrow the term from Bataille. This way, politics and religion can be bracketed in order to reveal the most basic cultural function of theatre. What is alive for those who live in the Polish language must have an origin in the mental sphere created by daily and extra-daily conventions, rational and irrational content in metaphors, yearnings, fears, desires, and revelations revealed by the birth of the word in the release of breath or a gasp of air in fear. Reduta was a national theatre in the most direct and primitive way - by approaching language as a site and means of the spirit, or as the spirit itself. Indeed, when writing on Reduta, it is easy to fall victim to the polarization of content: cultural against political and religious. Reduta's theatre - which includes a form of communal work and life and not merely productions - makes all aspects of a very broadly understood cultural action relevant, because the stage and the studio serve as an ontological laboratory in which all habitual meanings are retraced 
to their sources, that is, to their originating needs. In this process, the actor may be called a preacher or priest of the ceremony, but also a master and magician of meaning who plays with the signifiers to reconnect them with the lost signifieds. Similarly, even if exclusively through written language, Heidegger "reconnects" the earth, the sky, the mortals, and the immortals by looking for the nature of any thing (in his case, a simple jug) ${ }^{1}$. I call this Heideggerian act of "turning to the thing itself" an act of reorigination, particularly in the context of Osterwa's and Limanowski's work, and later in Grotowski's. For Heidegger, it happens through the means of poetic language which performs rather than states the meaning. In theatre, this process takes place through action and the totality of the experience that surrounds that action. Osterwa, like later Grotowski, found such reorigination more possible in the presence of those who have not been conditioned to consume theatre, but who nonetheless look for a communitas, ready to experience a transformation. The word becomes living when it reoriginates in the world, connecting its fragmented tissue. A word like that is at once a word and a deed. That's why the chapters on language in this volume are of particular importance.

Ewa Dulna-Rak writes on Osterwa's interest in language, which included creating neologisms - indeed a form or reorigination of the meaning depleted by conventional use and "forgetting." Osterwa's obsession with neologisms manifested itself in the form of multiple dictionaries. Dulna-Rak sources Osterwa's interest in Żeromski, whose project involved reclaiming old, forgotten words as well as words of folk origin. For Osterwa, a word had to be worshipped - it belonged to the sacred realm. One had to serve it. One had to sacrifice oneself for it. One had to love its beauty. The word had the power to rule over people, change their world, heal them, strengthen them, fulfill them. For Osterwa, such powers belong mainly to the spoken word; for all his admiration for literature, he preferred oral culture. When the word becomes living - when it is spoken in the way that it comes alive - it can "give life" (provide a sense of aliveness) to those who hear it. Here we are getting the meaning of "being alive" and "living" as the quality separate from the meaning of the word, delivered, to use Grotowski's term, through the process of induction. Grotowski formulated this notion when theorizing his last phase of lifework, Art as vehicle, in which aliveness of the performer's process was key.

New theatre needed new words, new names, approaches, meanings, mentality. It is hard to think in a new way using old words. Dulna-Rak takes her studies of Osterwa's work on reforming Polish language beyond theatre terminology, into other disciplines (for which he creates separate dictionaries), such as philosophy and religion, and even beyond the dictionaries, into grammar. Yet if we put it all together - his worship of words as deeds, his forced inactivity during the war, and

1 M. Heidegger, Poetry, Language, Thought, transl. A. Hofstadter, New York 1971. 
his advanced age - we see his laborious effort to reinvent (not simply reform) Polish language in the seclusion of his apartment as an act of sublimation, as much pedantic as neurotic. The fact that in his act Osterwa remained utterly uncompromised may be the strongest single lesson coming from his legacy.

Tadeusz Kornaś focuses on Limanowski as a scientist who significantly contributed to geological terminology. Unlike Osterwa's, his neologisms have been met with appreciation and remain in use. Yet Kornaś' portrayal, which presents the scientist-artist as an other in both art and science, also reveals Limanowski's way of processing thoughts which involve emotions and sensations of the body. His holistic approach - one defying the Cartesian split between the body and the mind would meet with confirmation by recent advancements in somaesthetics by Richard Schusterman. The ancient Greek word "soma" means the body with its emotional processes which, as experience shows, are involved in thinking of/relating to the world. Thus, Limanowski's embodied epistemology defies the boundary between art and science and expands knowledge beyond discourse. Even if Kornaś does not go that far in his article, he makes room for such conclusions.

Wanda Świątkowska points to the role of real objects in Reduta's work as fundamentally in service of the actors and only indirectly (often invisibly) for the audience's appreciation. However, it is hard for me to think of this approach as exclusive to Reduta. It would be difficult, if not impossible, to claim that Sax-Meiningen's, or Antoine's (even to some degree Stanislavsky's) use of authentic objects was strictly the result of representational ethics for the audience and not for the actors. It may be true, however, that Osterwa and Limanowski prioritized the actor's benefit over that of the spectators. Furthermore, Reduta could be seen as a theatre of the (Lacanian) Real - using the real to reveal the Real. There is no language in the Real, so we can only point to the experience of it via an unmediated intersubjective encounter. From the chapters on language, we gather that Reduta's radical reinvention of theatrical terms seemingly paradoxically goes along with the veneration of literary (particularly poetic) language. I say, "seemingly," to point to the way language "works," i.e. becomes a deed when it is "living," when it becomes "dead" and stops at the level of conventional function. Ultimately, the effort to turn the performance into a transformative deed goes beyond language, into an action that also goes beyond its symbolic function and communicates directly as an intersubjective reference. To put it differently, words and things are mere traces leading to the deep levels of the unconscious. However, it is not words or things themselves that grant us access to the Real - it is ultimately the position, approach, attitude of the speaker, observer, and doer, an approach that must be recognized as fundamentally phenomenological. To words themselves, to things themselves! By their (always reluctant) revealing of themselves they reveal our own being in the world. 